DOI: 10.34015/2523-4552.2021.1.03

УдК 355.9

\begin{abstract}
Колб О. Г., доктор юридичних наук, професор, заслужений юрист Украӥни, професор кафедри політології, управліннята державної безпеки Волинського національного університету імені Лесі Українки ORCID: 0000-0003-1792-4739
\end{abstract}

Пирожик О. В., радник першого заступника голови Волинської обласної ради депутат Волинської обласної ради

\title{
ЩОДО ЗМІСТУ ПОНЯТЬ «ІНФОРМАЦІЙНА ЗБРОЯ» ТА «ІНФОРМАЦІЙНИЙ ТЕРОРИЗМ» - ЯК ДЖЕРЕЛ ПОСЯГАНЬ НА НАЦІОНАЛЬНУ БЕЗПЕКУ УКРАЇНИ
}

У статті розглянуто питання, що стосуються застосування різноманітних інформаційних технологій при здійсненні посягань на основи національної безпеки України, та розроблені у зв'язку з цим науково обгрунтовані заходи, спрямовані на запобігання зазначеному суспільно-небезпечному явищу, 3 урахуванням існуючих на сьогодні потенційних та реальних загроз національним інтересам України.

Ключові слова: інформаційна безпека; національна безпека; пропаганда; санкції; тероризм; кібертероризм; медіа-тероризм; інформаційна зброя.

В статье рассмотрены вопросы, касающиеся применения различных информационных технологий при осуществлении посягательств на основы национальной безопасности Украины, и разработанные в связи с этим научно обоснованные меры, направленные на предотвращение указанного общественно-опасного явления, с учетом существующих на сегодня потенциальных и реальных угроз национальным интересам Украины.

Ключевые слова: информационная безопасность; национальная безопасность; пропаганда; санкции; терроризм; кибертерроризм; медиатерроризм; информационное оружие.

Постановка проблеми. Як показали результати вивчення наукової літератури, нормативно-правових актів та практики їх застосування, однією із ключових проблем, що стосуються змісту діяльності по забезпеченню інформаційної та національної безпеки України, є використання при запобіганні посягань на зазначені об'єкти правового захисту новітніх інформаційних технологій методик і підходів, серед яких особливе місце займає так звана «інформаційна зброя». Виходячи із цього та врахо- 
вуючи, що ні на доктринальному, ні на законодавчому рівнях це поняття не сформульовано, що негативно впливає на ефективність запобіжної діяльності із вказаних питань, актуальною є розробка цієї проблематики, з урахуванням існуючих на сьогодні потенційних і реальних загроз на національні інтереси України.

Зазвичай під цим поняттям розуміють набір технічних і технологічних засобів та прийомів, якими здійснюється «інформаційний тероризм». Поряд з цим слід зазначити, що як і перше, так і друге поняття можуть бути складовими більш загальних - «інформаційна агресія» та «гібридна агресія», 3 відповідними правовими наслідками для суб'єктів ïx вчинення проти людини та суспільства. Тобто, в законодавстві слід чітко прописати детермінанти та невідворотність покарання за здійснення таких злочинних діянь, якщо вони несуть загрозу інформаційній і національній безпеці. Це стало би додатковим обгрунтуванням санкційної політики держави в досліджуваних сферах.

3 огляду цього, слід визнати, що досліджувана проблематика $\epsilon$ актуальною та такою, що має теоретичне і практичне значення, а тому потребує активізації наукових розробок і пошуків у цьому напрямі.

Постановка завдання. Виходячи 3 цього, метою даної наукової статті $€$ обгрунтування необхідності підвищення ефективності запобіжної діяльності з питань, що стосуються інформаційної та національної безпеки України, 3 урахуванням сучасних новітніх технологій, методик і підходів, а також існуючих потенційних і реальних загроз, які посягають на національні інтереси України. при цьому головним завданням цієї статті $є$ з'ясування змісту такого поняття, як «інформаційна зброя», та розробка націй підставі науково обгрунтованих заходів, спрямованих на нейтралізацію, усунення, блокування тощо тих джерел, які посягають на інформаційну та національну безпеки України.

Аналіз останніх досліджень і публікацій. В епоху інформаційного суспільства феномену «інформаційної зброї» як засобу ведення інформаційної війни торкались у своїх працях як зарубіжні, так i окремі вітчизняні науковці. Серед теоретиків і практиків, які займалися дослідженням даної проблематики в умовах транскордонних глобалізованих процесів і розвитку інформаційного кіберпростору, варто виокремити роботи Д.Белла, Ж. Бодрійара, Е. Гіденса, М. Кастельса, Е. Тоффлера, Ф. Фукуями, С. Хантінгтона, Б. Хофмана та ін.

у свою чергу, дослідженню окремих проблем із зазначених аспектів та їх похідної - інформаційного тероризму, приділяють увагу в своїх роботах такі українські фахівці як: М. Зубок, В. Ліпкан, Ю. Максименко, Г. Почепцов, І. Рижов, А. Форос. Окремі аспекти цієї проблематики дослілджували Р. Банк, О. Бандурка, О. Бойченко, К. Герасименко, В. Ємельянов, О. Джужа, I. Кольцова, В. Коршунов, Л. Лабенко, А. Митко, В. Романов, Т.Яцик та ін. Однак, слід констатувати, що комплексний аналіз цього суспільнонебезпечного явища потребує подальших наукових досліджень, насамперед - у контексті його нормативно-правового закріплення, що й стало вирішальним при виборі теми цієї статті, її мети та завдання. 
Виклад основного матеріалу. Як свідчить практика, глобалізована інформатизація, хоч і вважається одним із важливих досягнень людства, проте вона помітно збільшує і можливості виникнення інформаційних загроз. Зважаючи на це, «інформаційну зброю» та «інформаційний тероризм» слід розглядати як засоби ведення інформаційної війни, що поєднує в собі біфуркаційні процеси (термін походить від лат. bifurcus - «роздвоєний» і вживається в широкому сенсі для позначення всіляких якісних перебудов чи метаморфоз різних об'єктів при зміні параметрів, від яких вони залежать) [1] фізичного тероризму, скорельованого в інформаційних системах та умисним зловживанням кіберпростором, мережами або їх компонентами $з$ метою сприяння здійсненню терористичних операцій [2]. Водночас у сучасних умовах це і засіб впливу на людські уми шляхом модифікування викривленої, хибної картини об'єктивної реальності, а його швидке поширення стало наслідком зомбування соціуму та активізації сепаратистського руху, що набуло нових загрозливих форм і за відсутності протидії та запобіжної діяльності держави з питань національної безпеки та, без сумніву, може загрожувати втратою суверенітету, незалежності та територіальної цілісності окремої держави.

Як $з$ цього приводу зробили висновок А. М. Митко та I. І. Кольцова інформаційний тероризм слід розглядати через призму соціального конформізму, тобто способу впливу антидержавних наративів (сукупності пов'язаних між собою реальних чи вигаданих подій, фактів або вражень, які складають оповідний текст) [3] на суспільну та громадську думку та масову свідомість і суспільну психологію. Інформаційний тероризм та зброю вони визначають як інструменти маніпулятивного впливу на інформаційний конформізм у глобальному середовищі [4]. При цьому слід констатувати, що коли фіксується наявність конфлікту між думкою індивіда і думкою групи та подолання цього конфлікту на користь групи, 3'являється явище конформності - схильності індивіда думці групової більшості, реальному чи уявному тиску групи, що можна розглядати як масово-психологічний терор, а також як одну із потенційних загроз національній безпеці України [5]. На їхню думку (і це не викликає у цілому заперечень), це метод «м'якої сили», осмислення феномену якого необхідне для запобігання деструктивного впливу на державні інститути та основи національної безпеки загалом [4].

Більш того, не заперечуючи такого трактування, слід звернути увагу саме на таких різновидах «інформаційної зброї» та «інформаційного тероризму», які пов'язані не стільки 3 техніко-технологічними впливами на інформаційні системи, скільки 3 інформаційно-психологічними впливами на свідомість та емоційний стан людини. Тобто, $є$ підстави вести мову про інформаційно-психологічні впливи на індивіда, чи соціальну групу, об'єктами яких є окремі особи, групи осіб та держави.

Такий підхід в науці $є$ непоодиноким. Зокрема, Л. В. Лабенко, розглядаючи інформаційний тероризм як один із видів тероризму, породженого стрімким розвитком інформаційних технологій, слушно зауважив, що існує тероризм психо- 
логічний, який не використовує засоби фізичного впливу на противника і розрахований на вплив інформацією, що призводить до ефекту залякування» (етимологічно слово «терор» якраз і походить від лат. «залякувати»). При цьому, на його переконання, маніпулювання свідомістю здійснюється шляхом занурення людей у певне кероване інформаційне поле, в якому створюється вигадана, маніпулятивна картина світу. Саме тому, «інформаційний тероризм охоплює політичні, філософські, правові, естетичні, релігійні та інші погляди й ідеї, тобто у духовній сфері, там, де ведеться боротьба ідей [6].

Відтак, феномен «інформаційного тероризму» можна структурувати за двома основними видами впливів - матеріальному та інтелектуальному. У першому випадку це - техніко-технологічні впливи на інформаційні системи, що полягає у здійсненні руйнівних впливів матеріального характеру, завдання збитків окремим елементам чи інформаційному середовищу в цілому, підриві їх цілісності та дієздатності (руйнація елементної бази, придушення ліній зв'язку, штучне перевантаження вузлів комунікації тощо). У другому випадку - це інформаційно-психологічний тероризм, спрямований на людську свідомість - індивідуальну чи колективну, що досягається через дезінформацію, дискредитацію, поширення чуток, неповної, неточної, недостовірної інформації, маніпулювання свідомістю мас, зомбування населення тощо.

Одним із різновидів інформаційно-психологічного (інтелектуального) тероризму та загроз у зв'язку з цим національній безпеці окремі дослідники розглядають також «медіа-тероризм». Його особливістю вони не безпідставно вважають комплексне зловживання інформаційними системами шляхом створення цілісної інструментальної бази, використання якої спрямоване на деструктивну пропаганду. Так, К. С. Герасименко 3 цього приводу вважає, що сутність «медіатероризму» полягає у спробах шляхом організації спеціальних медіакампаній дестабілізувати суспільство, створити у ньому атмосферу громадянської непокори, недовіри суспільства до дій та намірів влади й особливо - її силових структур, покликаних захищати суспільний порядок [7]. Як видається, з таким підходом можна погодитись, враховуючи, зокрема, ті загрози, що складають його сутність та соціальноінформаційну природу.

Виходячи 3 цього, найефективнішими $з$ інструментаріїв «медіатероризму» досі і науковці, і практики вважають засоби масової інформації (3MI) та мережу Інтернет, які формують інформаційний ракурс, здатний за абстрактною реальністю приховувати достовірну, точну та повну інформацію, а отже, потенційно створювати загрозу як інформаційній, так і в цілому національній безпеці України. При цьому, як показали результати даного дослідження, під впливом медіа-тероризму індивід стає не здатний самостійно орієнтуватися в необмеженому інформаційному просторі щодо доступних даних, тому що маніпулятивні масмедіа представлені як інструменти («інформаційна зброя») для конструювання не об'єктивної, а недостовірної, тобто потрібної реальності 
для певних суб'єктів інформаційної діяльності. Як видається, в цьому контексті не варто недооцінювати й ролі деструктивних телеканалів, які вдаються до маніпулювання громадською думкою та поширення дезінформуючого впливу на суспільство 3 метою психологічного зомбування соціуму та поширення одновекторної інформації, що в результаті формує ідеологію, прийнятну для терористів, а також детермінує розвиток тих чинників і загроз, що посягають на національну безпеку України.

Враховуючи зазначене та сучасний стан запобігання правопорушенням у сфері інформаційної безпеки України, в державі повинні бути достатні нормативно-правові інструменти запобіжного характеру, що у тому числі протидіють проявам та результатам застосування в інформаційному просторі як «інформаційної зброї» та «інформаційного тероризму» загалом, так і «медіатероризму» зокрема. Як свідчить у зв'язку з цим практика, Наразі ж в Україні фактично відсутня відповідна нормативно-правова база. Зокрема, у чинному законодавстві України не ведеться мова про зазначену термінологію, а тому, з проявами «інформаційної зброї», медіатероризмом та медіа-кілерством доводиться боротися, застосовуючи не завжди придатні до конкретного інформаційно-терористичного акту законодавчі норми, що не дозволяє у таких випадках нейтралізувати, блокувати або ліквідувати детермінанти, що обумовлюють наявність зазначених суспільно-небезпечних загроз в інформаційному просторі України. більш того, недосконалість чинної нормативно-правової бази наочно ілюструє багаторічна деструктивна діяльність в українському інформаційному просторі «інформаційних терористів» та «медіакілера», типу блогера Анатолія Шарія, якого лише нещодавно спробували притягнути до кримінальної відповідальності за протиправну діяльність на шкоду національній безпеці України в інформаційній сфері. Зокрема, підозру Шарію оголосили в межах кримінального провадження за двома статтями Кримінального кодексу України - ч. 1 ст. 111 (Державна зрада) та ч. 1 ст. 161 (Порушення рівноправності громадян залежно від їх расової, національної належності, релігійних переконань, інвалідності та за іншими ознаками) [8], хоча ця особа відкрито на протязі більше семи років реально посягала на основи національної безпеки України та, зокрема, iї інформаційну безпеку.

Виходячи із результатів даного дослідження, слід визнати, що зростаючі загрози інформаційній безпеці України як складової національної безпеки обумовлюють необхідність не тільки законодавчого унормування понятійно-категоріального апарату сфери інформаційної безпеки в Україні, а й упорядкування існуючої нормативно-правової бази з цих питань. Так, логічним у зв'язку з цим було б внесення відповідних змін у чинне законодавство України, у тому числі в Закон України «Про санкції», а саме: 3 метою забезпечення санкційної політики держави варто вже зараз, з урахуванням існуючих правових можливостей притягти «інформаційних терористів» чи «інформаційних кілерів» до відповідних видів юридичної відповідальності, включаючи передбачені законом 
санкції, за тероризм або ж фінансування тероризму.

Додатковим аргументом 3 цього приводу виступає той факт, що в Україні досі продовжує залишатися ряд телеканалів, які фактично є такими $є$ «інформаційними кілерами» чи «інформаційними агресорами», а фактично - пропагандистськими рупорами країн-агресорів та інших потенційних суб'єктів протиправної інформаційної діяльності в Україні. Так, за матеріалами, які наводить веб-сайт «Детектор медіа», посилаючись на дані, надані агенцією Vizeum Ukraine, після відключення каналів «112 Україна», NewsOne та ZIK найбільше зросли показники у каналу «Наш» [9]. При цьому його частка у перший день після відключення зросла у понад 3,5 разів, тобто аудиторія заблокованих телеканалів практично відразу перебралася до іншого проросійськи налаштованого пропагандистського телеканалу, що створило ще одну із потенційних загроз для національної безпеки України.

Варто також зауважити, що в Україні сьогодні існує чимало й місцевих (регіональних) антиукраїнськи налаштованих пропагандистських телеканалів, особливо на півдні та сході нашої держави, а відтак, потрібні інші, більш дієві та ефективні закони та підзаконні акти, які би не тільки протидіяли, а й запобігали ризикам і загрозам інформаційної та національної безпеки України. крім цього, як видається, повинні бути санкції не лише за «тероризм», а й за «інформаційний тероризм», що важливо з огляду як змісту запобіжної діяльності з цих питань, так і усунення детермінант, які породжують та обумовлюють наявність зазначе- них суспільно-небезпечних явищ. Більш того, за антидержавні дії, які становлять загрозу інформаційній та національній безпеці України, необхідно запроваджувати суворі кримінальні покарання, аж до довічного позбавлення волі. Такий підхід, без сумніву, дозволить вибудовувати таку нормативно-правову базу, яка б давала можливість запобігати як потенційним, так і реальним загрозам, що посягають на зазначені об'єкти правового захисту в Україні.

У цьому контексті, життєвонеобхідним можна визнати здійснення невідкладних заходів щодо визначення на законодавчому рівні понять «інформаційної зброї» та «інформаційного тероризму», а також кодифікації інформаційного законодавства України. Як видається, доцільним також було б закріплення в законодавстві юридичної відповідальності за «інформаційний тероризм», а саме - криміналізації цього суспільнонебезпечного діяння шляхом доповнення Кримінального кодексу (КК) України ст. 258-6 «Інформаційний терористичний акт» [2] наступного змісту : «Інформаційний терористичний акт, тобто, дії інформаційно-психологічного та інформаційно-технічного впливу, спрямовані на розв'язання суспільнополітичних, ідеологічних, національних, територіальних конфліктних ситуацій з метою маніпулювання та зомбування свідомості особи чи широкого кола осіб шляхом реалізації способів і методів інформаційного насильства, застосування інформаційної зброї - караються виправними роботами на строк до двох років або арештом на строк до шести місяців, або обмеженням волі на 
строк до трьох років, або позбавленням волі на той самий строк 3 конфіскацією майна або без такої».

Зазначений підхід, без сумніву, дозволить видозмінити зміст запобіжної діяльності, пов'язаної 3 нейтралізацією потенційних і реальних загроз, що стосуються інформаційної та національної безпеки, та здійснювати у зв'язку з цим тактичні випереджувальні та наступальні ефективні заходи. Саме тому, важливим у цьому контексті $\epsilon$ прийняття нових законів та підзаконних актів, які би відповідали викликам і вимогам часу у сферах інформаційної та національної безпеки, а також запобігали «інформаційному тероризму», «інформаційному кілерству», «інформаційній агресії» та «гібридній агресії». Назрілим на часі та необхідним у зв'язку з цим видається необхідність невідкладного обговорення та прийняття парламентом законопроєкту щодо встановлення кримінальної відповідальності за колабораціонізм (від фр. collaboration - «співробітництво»). Відповідний проєкт [10] зареєстрований у Верховній Раді України та передбачає, зокрема, доповнення КК України ст. 111-1. «Колабораціонізм» [11].

При цьому слід зазначити, що уданому законопроєкті колабораціонізм визнається як особлива форма державної зради, яка полягає у військовому, політичному, економічному, адміністративному, культурному, інформаційному, медійному співробітництві громадянина України з державою-агресором або їі представниками, створеними чи підтримуваними нею незаконними збройними формуваннями, яке завдало шкоди державному суверенітету, територіальній цілісності та недоторканності, обороноздатності, державній, економічній чи інформаційній безпеці України, - і караються позбавленням волі на строк від трьох до п'яти років 3 конфіскацією майна або без такої. Ті самі дії, якщо вони вчинені особою, яка $\epsilon$ представником влади, або повторно, або за попередньою змовою групою осіб, або поєднані з розпалюванням національної чи релігійної ворожнечі, - караються позбавленням волі на строк від п'яти до десяти років 3 конфіскацією майна або без такої. Дії, передбачені частинами першою або другою цієї статті, які призвели до загибелі людей або інших тяжких наслідків, - караються позбавленням волі на строк від десяти до п'ятнадцяти років або довічним позбавленням волі 3 конфіскацією майна або без такої.

Як видається, важливим у контексті запобігання інформаційним загрозам, можна визнати ст. 4 цього законопроєкту, згідно 3 яким «Публічні заклики до колабораціонізму, а також виготовлення матеріалів із закликами до колабораціонізму 3 метою їх розповсюдження або розповсюдження таких матеріалів - караються виправними роботами на строк до двох років або арештом на строк до шести місяців, або позбавленням волі на строк до трьох років».

Висновки. Враховуючи отримані в ході даного дослідження результати, слід констатувати, що не дивлячись на прийняття останнім часом ряду нормативно-правових актів, що стосуються забезпечення інформаційної та національної безпеки, центральною виконавчою владою України, необхідність їх удосконалення та упорядкування нормативно- 
правової бази 3 цих питань $\epsilon$ об'єктивно обумовленою, з урахуванням сучасних потенційних і реальних загроз у виді застосування «інформаційної зброї», «інформаційного тероризму», «медіа-кілерству» та тому подібних протиправних посягань на зазначені об'єкти правової охорони. Саме з цих міркувань, у даній нау- ковій статті вчинена спроба обгрунтувати здійснення відповідних заходів, спрямованих на вирішення означеної проблематики, а головне на усунення, блокування, нейтралізацію тощо тих детермінант, що породжують джерела посягань на інформаційну та національну безпеку України.

\section{Список використаних джерел}

1. Біфуркація. Вікіпедія. URL: https://uk.wikipedia.org (дата звернення: 12.02.2021).

2. Банк Р. О. Інформаційний тероризм як загроза національній безпеці України: теоретико-правовий аспект. Інформація і право. 2016. № 1 (16). Ст. 110-116.

3. Наратив. Вікіnедія. URL: https://uk.wikipedia.org_(дата звернення: 12.02.2021).

4. Митко А. М., Кольцова I. I. Інформаційний тероризм як інструмент впливу на інформаційний конформізм в глобальному середовищі. Політичне життя. 2018. № 2. C. $135-139$.

5. Конформність. Вікіпедія. URL: https://uk.wikipedia.org (дата звернення: 12.02.2021).

6. Лабенко Л. В. Інформаційний тероризм: поняття та ознаки. Міжнародні читання присвячені пам'яті професора Імператорського Новоросійського університету П. Є. Казанського: матеріали Міжнародної конференції (м. Одеса, 22-23 жовтня 2010 року). Одеса: Фенікс, 2010. С. 195-198.

7. Герасименко К. С. Сучасні ознаки загроз «інформаційного тероризму». Форум права. 2009. № 3. С. 162-166.

8. СБУ оголосила про підозру відомому проросійському пропагандисту Шарію. Служба безпеки Украӥни. Офіційний сайт. URL: https://ssu.gov.ua/novyny/sbu-oholosylapro-pidozru-vidomomu-prorosiiskomu-propahandystu-shariiu (дата звернення: 12.02.2021).

9. Після відключення «каналів Медведчука» утричі краще стали дивитися канал Мураєва «Наш». Детектор медіа. URL: https://detector.media/rinok/ article/184618/2021-02-05-pislya-vidklyuchennya-kanaliv-medvedchuka-utrychikrashche-staly-dyvytysya-kanal-muraieva-nash/ (дата звернення: 12.02.2021).

10. Закон України «Про внесення змін до деяких законодавчих актів України (щодо встановлення кримінальної відповідальності за колабораціонізм)»: проєкт. Верховна Рада України. Офіційний веб-портал. URL: http://w1.c1.rada.gov.ua/ pls/zweb2/webproc4_1?pf3511=67568 (дата звернення: 12.02.2021).

11. Кримінальний кодекс України: прийнятий 05 квітня 2001 року. Відомості Верховної Ради України. 2001. № 25-26. Ст.131.

\section{References}

Bank, R. O. (2016). Informatsiinyi teroryzm yak zahroza natsionalnii bezpetsi Ukrainy: teoretyko-pravovyi aspekt. Informatsiia i pravo, 1 (16), 110-116.

Mytko, A. M., Koltsova, I. I. (2018). Informatsiinyi teroryzm yak instrument vplyvu na informatsiinyi konformizm v hlobalnomu seredovyshchi. Politychne zhyttia, 2, 135-139.

Labenko, L. V. (2010). Informatsiinyi teroryzm: poniattia ta oznaky. Materialy Mizhnar. konf. (m. Odesa, 22-23 zhovtnia 2010 roku). Odesa: Feniks, 195-198. 
Herasymenko, K. S. (2009). Suchasni oznaky zahroz «informatsiinoho teroryzmu». Forum prava, 3, 162-166.

A.Kolb, Doctor of Law, Professor, Honored Lawyer of Ukraine, Professor of the Department of Political Science, Management and State Security of Lesya Ukrainka Volyn National University

ORCID: 0000-0003-1792-4739

o. Pirozhik, Advisor to First Deputy Head Volyn Regional Council, MP of the Volyn Regional Council

\section{Regarding the content of the concepts of "Information Weapons" and "Information Terrorism" - sources of encroachments for the national security of Ukraine}

The article deals with the application of various information technologies in implementing encroachments on the basis of national security of Ukraine, and developed in this regard, scientifically substantiated measures aimed at preventing said socio-hazardous phenomenon, taking into account existing national and real threats to national and real threats. the interests of Ukraine.

Proceeding from this, it is proved that the latest decisions of the Ukrainian authorities regarding sanctions against pro-Russian propaganda TV channels are determined by a number of objective and subjective factors. In particular, unnecessary activities in Ukraine are non-state in the form and anti-state on the content of the media with a wide viewer audience, which systematically distribute and systematically distribute the narrative of Russian propaganda in Ukraine. In this context, attention was drawn to the fact that since the beginning of the armed aggression of the Russian Federation against Ukraine and in fact, their activities remained unpunished and without the proper sanational policy of the Ukrainian state, which has adversely affected the state of protecting national interests and, in particular information security.

At the same time, as shown by the study of practice, Ukraine's current legislation does not solve this issue, since the issued problem is limited to literally several laws that make it possible to adequately liaise those who are threatening information and national security. Language, first of all, is conducted on the Law of Ukraine "On Sanctions", the scope of which is rather limited and does not allow the violator to be prosecuted for the actions that are obvious signs of "Information Terrorism". Consequently, it should be recognized that in the presence - a complex application that requires an urgent solution, including the theoretical level, namely, as shown by the results of the analysis of scientific, normative legal and other so sources, to subjective factors of sharp activation and the actual change in the sanctional policy of the current central Ukrainian authorities can be with great probability to attribute the desire of the ruling elevation to return electoral leadership after his loss of the political party "Servant of the people" and exit the electoral leaders of the pro-Russian political party "United Platform - For Life", which showed the data of an all-Ukrainian survey of public opinion, conducted from January 27 to February 1, 2021, Kyiv International Institute of Sociology. 
Moreover, as it is proved on the doctrinal level, the ratings of OPPP is consistently and purposefully "closed" precisely because of the means of television communication by unlawful influence on the audience pro-Russian narratives (a set of connected real or fictitious events, facts or impressions that make up the narrative Text), indicating the presence of domestic political determinants that determine the attack on the information security of Ukraine, as well as the use of the so-called information weapons in this process, that is, a set of technical and technological means and techniques that "Information Terrorism" is carried out.

Keywords: Information Security; National security; propaganda; sanctions; terrorism; cybertrorism; media terrorism; Information weapons. 